\title{
Cost of Production for Fresh Market Grapefruit Grown in Indian River, 2017/18
}

\author{
Ariel Singerman ${ }^{2}$
}

This article presents the cost of production per acre for growing fresh grapefruit in the Indian River region during $2017 / 18$. The data was collected during a production committee meeting of the Indian River Citrus League in May 2018.

Seven grapefruit growers participated in the survey. Growers brought a completed survey form to the meeting that had been distributed to them beforehand. The questionnaire asked growers to provide annual, per-acre costs by program for a "typical" irrigated, mature grapefruit grove $(10+$ years old) with fruit marketed to the fresh market, including costs related to their tree replacement program.

During the meeting each grower used a "clicker" or remote device to enter the costs for each caretaking program. Using clickers to collect the data kept the process anonymous and confidential. Surveying a panel of growers to obtain the costs of their production programs allows me to report estimates that closely reflect growers' costs. This is particularly important because, since the outbreak of huanglongbing (HLB; citrus greening), growers have been modifying their practices from year to year in an attempt to cope with the disease. However, the cost estimates below do not represent any individual operation. Instead, their purpose is to serve as a benchmark for the Florida citrus industry.

The figures below were obtained by computing the weighted average of the responses by the acreage of each of the participating growers. The area managed by their combined operations accounts for approximately 12,210 acres. The acreage for grapefruit in the Indian River region in 2017 was estimated at 26,378 (USDA-NASS 2018). Thus, the sample of growers represented $46 \%$ of the acreage devoted to grapefruit in that region.

Table 1 shows the cultural costs of production by program. Such estimates include both the costs of materials and the costs of their application. At \$1,189.54 per acre, foliar sprays represented the largest production cost. Fertilizer was the second largest expense at $\$ 516.64$ per acre. Coordinated sprays accounted for $\$ 10.00$ per acre. From Table 1, the total for weed management, which includes chemical and mechanical mowing as well as herbicides, was $\$ 226.46$ per acre. The expense for pruning was $\$ 82.16$ per acre, while that for irrigation was $\$ 214.21$ per acre. The cost of canker control was $\$ 65.83$ per acre. Adding all the costs listed above, the cultural cost of growing fresh grapefruit in the Indian River region during 2017/18 without tree replacement was $\$ 2,304.85$ per acre.

Growers were also asked to provide details regarding their reset practices, including the number of trees replaced in their groves. On average, growers replaced one tree per acre during 2017/18. The total cost of tree replacement, including tree removal, site preparation, and care of those young trees was estimated at $\$ 45.90$ per acre. Adding this figure to the total cost above resulted in a total production cost with tree replacement of $\$ 2,350.75$ per acre.

1. This document is FE1066, one of a series of the Food and Resource Economics Department, UF/IFAS Extension. Original publication date August 2019. Visit the EDIS website at https://edis.ifas.ufl.edu for the currently supported version of this publication.

2. Ariel Singerman, assistant professor and Extension economist, Food and Resource Economics Department; UF/IFAS Citrus Research and Education Center, Lake Alfred, FL 32850

The Institute of Food and Agricultural Sciences (IFAS) is an Equal Opportunity Institution authorized to provide research, educational information and other services only to individuals and institutions that function with non-discrimination with respect to race, creed, color, religion, age, disability, sex, sexual orientation, marital status, national origin, political opinions or affiliations. For more information on obtaining other UF/IFAS Extension publications, contact your county's UF/IFAS Extension office. U.S. Department of Agriculture, UF/IFAS Extension Service, University of Florida, IFAS, Florida A \& M University Cooperative Extension Program, and Boards of County Commissioners Cooperating. Nick T. Place, dean for UF/IFAS Extension. 
Figure 1 depicts a double pie chart. The larger pie shows the cost of each program as well as the percentage relative to the cultural production costs with tree replacement. The smaller pie in Figure 1 provides greater detail regarding the individual components included in foliar sprays for a total of $\$ 1,189.54$ per acre. Insecticides accounted for $\$ 237.00$ per acre and represented $10 \%$ of the cultural cost of production; fungicides accounted for $\$ 218.60$ per acre (9\%); foliar nutritionals for $\$ 201.80$ per acre (9\%); aerial application for $\$ 5.34$ per acre $(0.23 \%)$; ground application of materials for $\$ 431.60$ per acre $(18 \%)$.

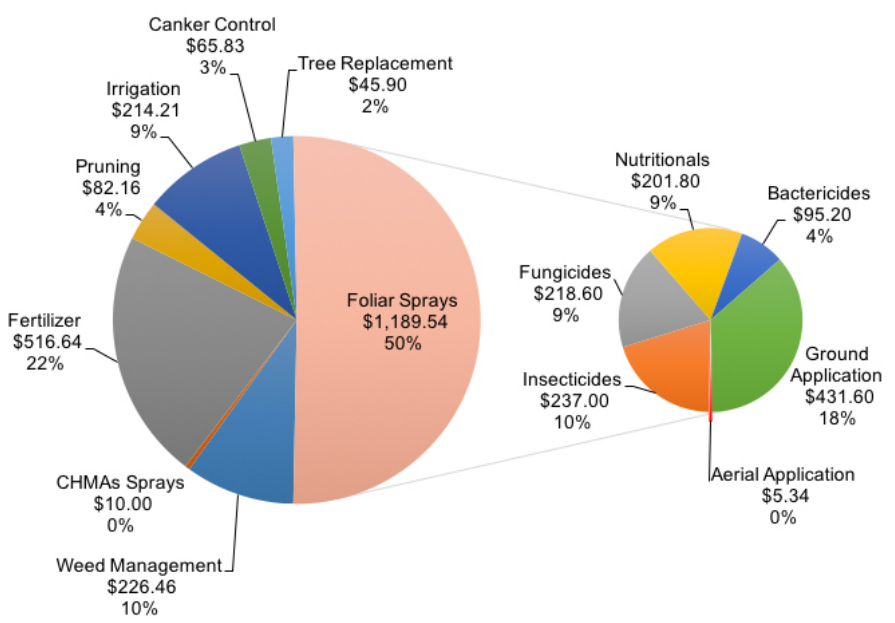

Figure 1. Cultural costs of production (in dollars per acre) for fresh market grapefruit grown in Indian River, Florida, 2017/18.

Figure 2 shows a comparison of the cost of the main production programs in $2017 / 18$ relative to the previous season. The main changes in cultural practices compared to the previous season are as follows. First, there was an increase of $\$ 114$ per acre in fertilizer spending. This was due to a switch from dry to liquid fertilizer. The rationale for this change is based on the successful experience of some growers in "spoon-feeding" trees to increase yield. The second-largest change was a reduction in tree replacement; growers replaced only one tree per acre instead of two as in the previous season. The third-largest change was a reduction in streptomycin and oxytetracycline spending; growers reported spending, on average, $\$ 95$ per acre, down from \$141 last season.

In addition to cultural costs, growers typically have to incur other costs when managing their groves; these other costs include management, regulatory, and opportunity costs. Table 2 shows the estimated total cost of production for fresh grapefruit growers in Indian River during 2017/18 was $\$ 2,884.39$ per acre. Based on this estimate, the breakeven prices per box for different levels of yield are presented in Table 3. Break-even prices were calculated on an on-tree

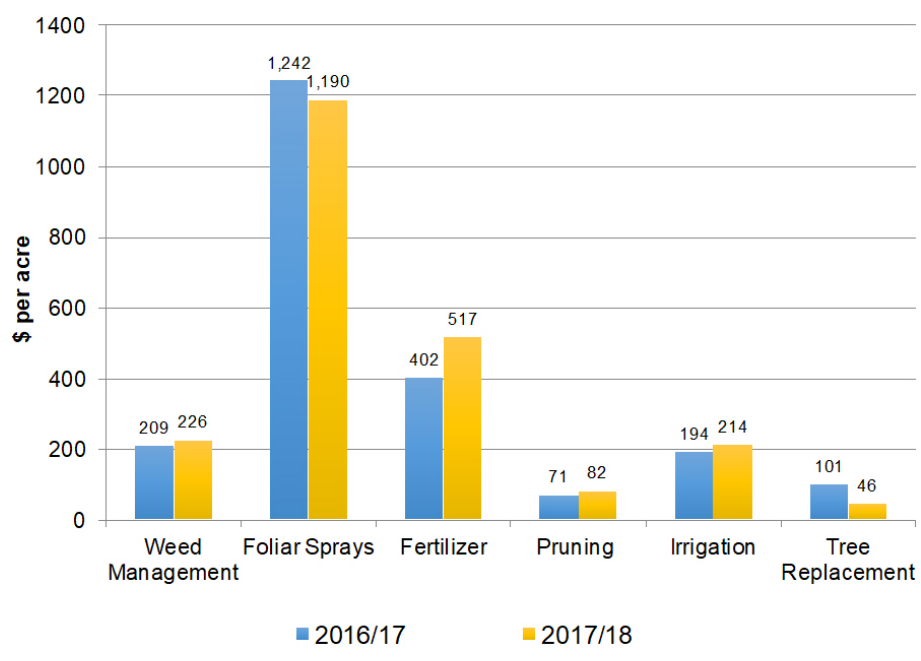

Figure 2. Cost of production by program for fresh market grapefruit grown in Indian River, Florida, 2016/17 vs. 2017/18.

and delivered-in basis. The latter assumes harvesting costs per box for fresh grapefruit were $\$ 2.55$, which is based on the results of Singerman and Burani-Arouca (2018). The calculations in Table 3 also include the Florida Department of Citrus (FDOC) assessment of $\$ 0.07$ per box for grapefruit. Thus, for example, the on-tree and delivered-in break-even prices for covering the total costs of production with yield at 300 boxes per acre were $\$ 11.44$ and $\$ 13.55$ per box, respectively.

\section{Summary}

This article presents a summary of the costs of production for fresh market grapefruit grown in the Indian River region during 2017/18. The methodology chosen to collect the data consisted of surveying growers directly to closely reflect growers' costs in the era of HLB. The main change this season was the increase in fertilizer spending as growers attempted to "spoon-feed" HLB-affected trees to increase yield. The total cost of production for fresh grapefruit in Indian River during 2017/18 was $\$ 2,884.39$ per acre. Typical users of the estimates presented herein include growers and consultants, who use them as a benchmark; property appraisers, who use them to compute the taxes for property owners; and researchers, who use the estimates to evaluate the economic feasibility of potential new technologies.

\section{References}

Singerman, A., and M. Burani-Arouca. 2018. Harvesting Charges for Florida Citrus, 2017/18. Available at: http:// www.crec.ifas.ufl.edu/extension/economics/harvesting_charges.shtml

USDA-NASS. 2018. Florida Citrus Statistics 2016/17. 
Table 1. Cultural Costs of Production per Acre for Fresh Market Grapefruit Grown in Indian River, Florida, 2017/18.

\begin{tabular}{|c|c|c|c|c|}
\hline $\begin{array}{l}\text { Costs represent a mature grove }(10+\text { years old }) \\
\text { including resets }\end{array}$ & $\begin{array}{l}\text { Number of } \\
\text { Applications }\end{array}$ & $\begin{array}{l}\text { Materials Cost } \\
\text { per acre (\$) }\end{array}$ & $\begin{array}{l}\text { Application Cost } \\
\text { per acre (\$) }\end{array}$ & $\begin{array}{l}\text { Total Cost per acre } \\
\text { (\$) }\end{array}$ \\
\hline \multicolumn{5}{|l|}{ Production/Cultural Costs } \\
\hline \multicolumn{5}{|l|}{ Weed management } \\
\hline Mowing chemical and mechanical) & 9 & 2.75 & 63.08 & 65.83 \\
\hline Herbicides & 4 & 95.16 & 65.47 & 160.63 \\
\hline \multicolumn{4}{|l|}{ Total weed management costs } & 226.46 \\
\hline \multicolumn{5}{|l|}{ Foliar sprays } \\
\hline \multicolumn{2}{|l|}{ Insecticides } & 237.00 & & 237.00 \\
\hline \multicolumn{2}{|l|}{ Fungicides } & 218.60 & & 218.60 \\
\hline \multicolumn{2}{|l|}{ Nutritionals } & 201.80 & & 201.80 \\
\hline \multicolumn{2}{|l|}{ Bactericides } & 95.20 & & 95.20 \\
\hline \multicolumn{5}{|l|}{ Application: } \\
\hline Ground & 11 & & 431.60 & 431.60 \\
\hline Aerial & 1 & & 5.34 & 5.34 \\
\hline \multicolumn{4}{|l|}{ Total foliar sprays costs } & $1,189.54$ \\
\hline CHMA sprays & 1 & & 10.00 & 10.00 \\
\hline \multicolumn{4}{|l|}{ Total CHMA sprays costs } & 10.00 \\
\hline \multicolumn{5}{|l|}{ Fertilizer } \\
\hline Ground/dry fertilizer & 3 & 185.59 & 26.98 & 212.56 \\
\hline Fertigation/liquid fertilizer & 19 & 281.77 & 22.31 & 304.08 \\
\hline \multicolumn{4}{|l|}{ Total fertilizer costs } & 516.64 \\
\hline \multicolumn{5}{|l|}{ Pruning } \\
\hline Topping, hedging and skirting & 1 & & 82.16 & 82.16 \\
\hline \multicolumn{4}{|l|}{ Total pruning costs } & 82.16 \\
\hline \multicolumn{5}{|l|}{ Irrigation } \\
\hline \multicolumn{4}{|l|}{ Irrigation system ${ }^{1}$} & 150.16 \\
\hline \multicolumn{4}{|l|}{ Fuel for pump } & 64.05 \\
\hline \multicolumn{4}{|l|}{ Total irrigation costs } & 214.21 \\
\hline \multicolumn{4}{|l|}{ Canker control costs ${ }^{2}$} & 62.83 \\
\hline \multicolumn{4}{|c|}{ Total production/cultural costs without tree replacement } & $2,304.85$ \\
\hline \multicolumn{5}{|c|}{ Tree replacement ( 1 tree): } \\
\hline \multicolumn{4}{|c|}{ Tree removal (clip-shear; use front-end loader) } & 8.50 \\
\hline \multicolumn{4}{|c|}{ Site preparation and plant tree (includes reset trees) } & 12.40 \\
\hline \multicolumn{4}{|c|}{ Supplemental fertilizer, sprays, sprout, etc. (trees 1-3 years old) } & 25.00 \\
\hline \multicolumn{4}{|l|}{ Total tree replacement costs } & 45.90 \\
\hline \multicolumn{4}{|l|}{ Total production/cultural costs with tree replacement } & $2,350.75$ \\
\hline $\begin{array}{l}{ }^{1} \text { Irrigation system includes: emitter maintenance an } \\
{ }^{2} \text { Canker control includes: cleaning of blocks before } \\
\text { citrus canker decontamination costs }\end{array}$ & $\begin{array}{l}\text { airs, ditch clean } \\
\text { ication and harv }\end{array}$ & $\begin{array}{l}\text { tch and canal mai } \\
\text {; inspections befo }\end{array}$ & $\begin{array}{l}\text { "'nance, water contro } \\
\text { "Canker Free" certific }\end{array}$ & ions; mandatory \\
\hline
\end{tabular}


Table 2. Total Costs of Production per Acre for Fresh Market Grapefruit Grown in Indian River, Florida, 2017/18

\begin{tabular}{|l|l|c|}
\hline \multicolumn{2}{|l|}{} & \multicolumn{1}{|c|}{ Cost per acre (\$) } \\
\hline \multicolumn{2}{|l|}{ Total cultural cost of production } & $2,350.75$ \\
\hline Other costs & Interest on operating (cultural) costs & 117.54 \\
\hline & Management cost & 71.25 \\
\hline & Property tax/water management tax & 18.50 \\
\hline & Fly protocol & 23.00 \\
\hline & Water drainage district assessment & 107.00 \\
\hline Total other costs & Interest on average capital investment & 196.35 \\
\hline Total grower costs & & 533.64 \\
\hline
\end{tabular}

Table 3. Break-Even Price per Box for Fresh Market Grapefruit Grown in Indian River, Florida, 2017/18

\begin{tabular}{|c|c|c|c|c|c|c|c|c|c|}
\hline & \multicolumn{9}{|c|}{ Yield (boxes per acre) } \\
\hline & 175 & 200 & 225 & 250 & 275 & 300 & 325 & 350 & 375 \\
\hline & \multicolumn{9}{|c|}{ Dollars per acre } \\
\hline Cost of production & 2,884 & 2,884 & 2,884 & 2,884 & 2,884 & 2,884 & 2,884 & 2,884 & 2,884 \\
\hline Pick and haul & 444 & 508 & 571 & 634 & 698 & 761 & 825 & 888 & 952 \\
\hline FDOC assessment & 12 & 14 & 16 & 18 & 19 & 21 & 23 & 25 & 26 \\
\hline $\begin{array}{l}\text { Total delivered-in } \\
\text { cost }\end{array}$ & 3,341 & 3,406 & 3,471 & 3,536 & 3,602 & 3,667 & 3,732 & 3,797 & 3,862 \\
\hline Break-even price': & \multicolumn{9}{|c|}{ Dollars per box } \\
\hline On-tree & 24.65 & 20.69 & 17.61 & 15.14 & 13.12 & 11.44 & 10.02 & 8.80 & 7.74 \\
\hline Delivered-in & 26.76 & 22.80 & 19.72 & 17.25 & 15.23 & 13.55 & 12.13 & 10.91 & 9.86 \\
\hline
\end{tabular}

${ }^{1}$ Assumes $71 \%$ packout, $27 \%$ field run, price of eliminations $\$ 6.78 /$ box and $\$ 8.30 /$ box for field run 